\title{
Phytocontact Dermatitis: A Case Study
}

\section{Fitokontakt Dermatit: Olgu Sunumu}

\author{
Elif Değirmenci', Neşe Duman², Afife Mat', Işıl Bavunoğlu4, İbrahim İkizceli5, Can Aktaş' \\ 'Department of Emergency Medicine, Koç University Faculty of Medicine, İstanbul, Turkey \\ ²Department of Emergency Medicine, Gaziantep Dr. Ersin Aslan State Hospital, Gaziantep, Turkey \\ Department of Pharmacognosy, İstanbul University Faculty of Pharmacy, İstanbul, Turkey \\ ${ }^{4}$ Department of Internal Medicine, İstanbul University Cerrahpaşa Faculty of Medicine, İstanbul, Turkey \\ ${ }^{5}$ Department of Emergency Medicine, İstanbul University Cerrahpaşa Faculty of Medicine, İstanbul, Turkey
}

\section{ABSTRACT}

Introduction: Herbal medicines are used for different purposes by applying them directly to the skin.

Case Report: A 57-year-old female patient presented with erythema and swelling of the left knee. On examination, erythematous and bullous lesions were observed. In the story of 'Ranunculus Scleratus' plants 12 hours knee closed contact of the learned. Diagnosis; Fitokontakt thought of as Dermatitis patients to wet dressing is recommended. 1 month after hyperemia outside of a clinical finding out.

Conclusion: Treatment with plants in our community are used as often as incorrect use can lead to harmful effects.

Keywords: Ranunculus Scleratus, phytocontact dermatitis, treatment

Received: 03.04.2015 Accepted: 08.06.2015

Available Online Date: 29.06.2015

\section{ÖZET}

Giriş: Bitkisel ilaçlar doğrudan cilde uygulanarak farklı amaçlarla kullanılamaktadır.

Olgu Sunumu: 57 yaşında bayan hasta sol dizine kızarıklık ve şişlik nedeniyle başvurdu. Muayenesinde eritamatöz ve büllöz lezyonlar görüldü. Hikayesinde 'Ranunculus Scleratus' isimli bitkiyi 12 saat dizine kapalı olarak temas ettiği öğrenildi. Tanısı; Fitokontakt Dermatit olarak düşünülen hastaya ıslak pansuman önerildi. 1ay sonra hiperemi dışında bir klinik bulgu kalmadı. Bitkilerle tedavi toplumuzda sık olarak kullanılmakta olup yanlış kullanım zararlı etkilere yol açmaktadır.

Sonuç: Bitkilerle tedavi toplumumuzda sık olarak kullanılmakta olup yanlış kullanım zararlı etkilere yol açmaktadır.

Anahtar Kelimeler: Ranunculus scleratus, fitokontakt dermatit, tedavi

Geliş Tarihi: 03.04.2015 Kabul Tarihi: 08.06.2015

Çevrimiçi Yayın Tarihi: 29.06.2015

\section{Introduction}

To date, herbal medicines have been applied to the skin for different purposes (1). The medical use of some herbal materials has both some beneficial and harmful effects. In the wrong hands, particularly when instructed by people without medical knowledge, the incidence of adverse events is higher because the patients are incorrectly instructed with respect to dosage and the route of administration. Particularly, in topical herbal treatments, contact dermatitis is a common adverse event. In this study, we aimed to represent a case of contact dermatitis related with the topical use of Ranunculus sceleratus.

\section{Case Report}

A 57-year-old female patient was admitted to our emergency room with redness and swelling in her left knee. Her medical history revealed that she was having pain in her knee and therefore she was using a herb called "cursed buttercup," which refers to "Ranunculus scleratus." She claimed that she was pressing the herb and applying it on the knee and then covering it with a piece of cloth and keeping it for almost $12 \mathrm{~h}$ (Figure 1). In her left knee, there were erythematous and bullous lesions of $15 \times 25 \mathrm{~cm}$, whereas the 


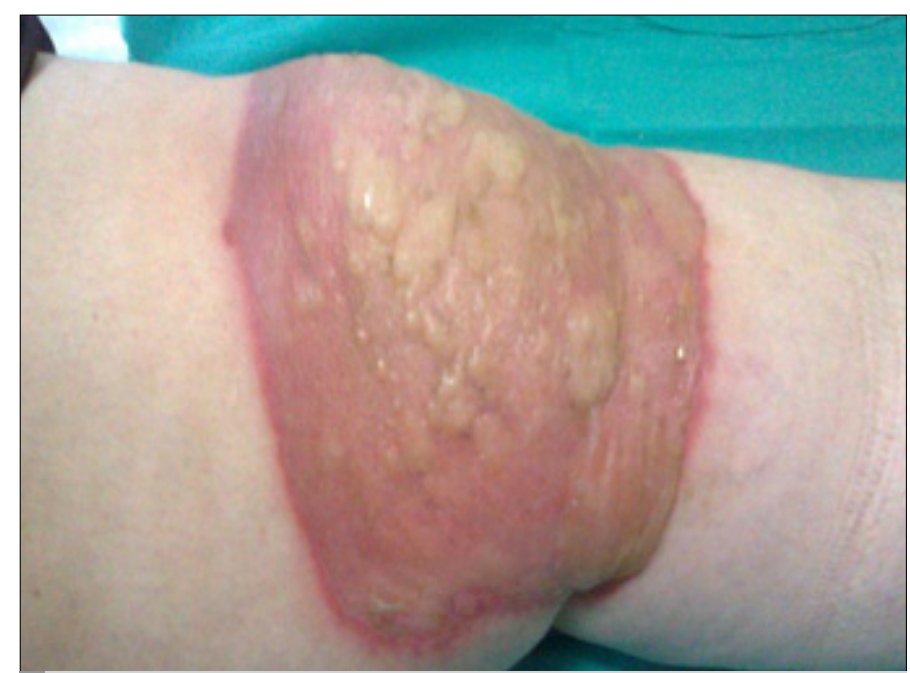

Figure 1. There were erythematous and bullous lesions of $15 \times 25$ $\mathrm{cm}$ in the patient's left knee.

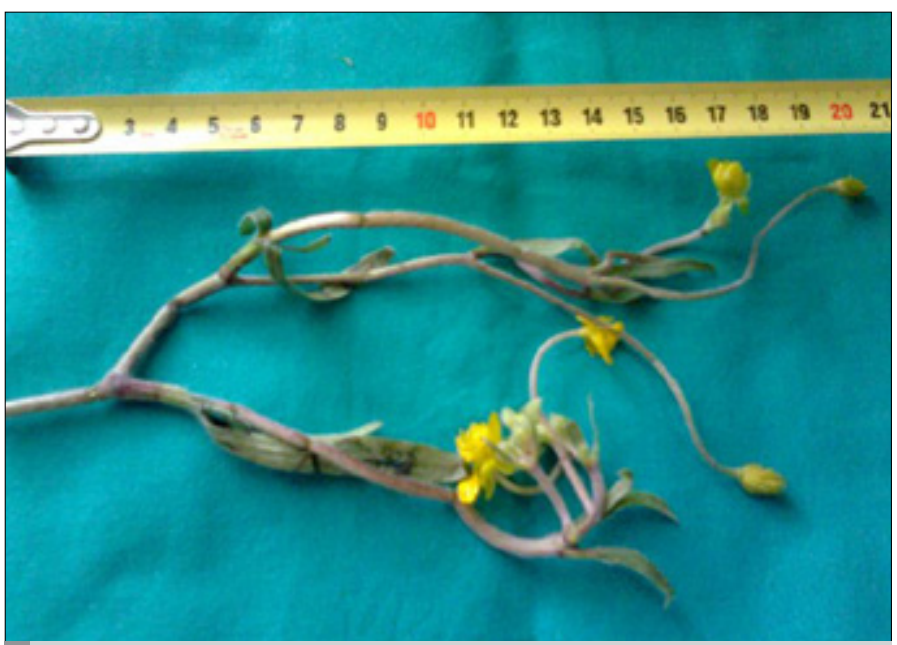

Figure 2. Ranunculus scleratus

rest of the systemic examination did not show any significance (Figure 2). The routine biochemical parameters as well as the hemogram were normal. The patient was thought to have Ranunculus scleratusrelated contact dermatitis. For the treatment, wet medical dressing was applied daily, and no further medical treatment was required. On the third day, a decrease in the erythematous and bullous lesions was reported. At the end of a week, because the erythematous region regressed and the bullous lesions were no longer present, the treatment was discontinued. At the follow-up visit after a month, the patient only had hyperemia in the lesion area.

\section{Discussion}

Ranunculus scleratus is a common species of buttercup which has rare toxicological and pharmacologic activities (2). Ranunculus Scleratus, known as "cursed buttercup" or "celery-leaved buttercup" grows mostly in winter. It grows in humid areas such as shallow water and mud, particularly in Britannia. The roots of the herb are fibrous, fat, erect, and trough. It grows to approximately $60 \mathrm{~cm}$ (3).
In all Ranunculus species, there are glycosidic or protoanemonin precursors that are tissue irritants (4). Ranunculus toxicity is attributed to DNA polymerase and radical oxygen species derived from previously mentioned inhibitors. Protoanemonin is a volatile, highly irritant oil derivative and it inhibits mitosis in herbs. Its contact with the skin destructs the sulfur bonds and therefore leads to sub-epidermal dissociation and bullous formations.

There are new modalities that are becoming popular these days, such as aromatherapy, phytotherapy, and herbal therapy. These new methods cause an exposure to herbal materials. Phytodermatitis is subdivided into three groups: Irritant phytodermatitis, Allergic phytodermatitis, and phytophotodermatitis (5).

In daily life, many people use Ranunculus species for traditional treatment for drainage of abscesses, hemorrhoids, burns, vesicles, lacerations, and abrasions; these herbs are also used for myalgia, flu, and other diseases (5). In Turkey, there are several indications for the use of herbal treatment; however, the most common indication is rheumatological diseases (6). Vesicles may be misdiagnosed as burns and therefore treated in plastic surgery clinics (7).

Protoamin compounds may lead to several problems if ingested by adults or children. These problems are faulty taste and burn in the mouth or nose. Other symptoms are abdominal pain and diarrhea. Vomiting or intestinal lavage do not necessarily occur in these cases (3).

According to the literature findings, it is reported that the lesions regressed in 3-4 days in the Ranunculus-related contact dermatitis cases if oral topical antibiotics or oral antihistamines are taken and wet medical dressing is applied. In our study, we only applied wet medical dressing and did not administer oral topical antibiotics or antihistamines. Also, in our case, the lesions were regressed after the third day.

\section{Conclusion}

Ranunculus scleratus-related contact dermatitis is rare and these cases may be referred to emergency clinics. When erythematous or bullous lesions are observed in patients, it will be suitable to question the use of topical herbal treatments. If no other findings are present rather than local irritation, it is adequate to provide wet medical dressing treatment and further treatments are not necessary.

Informed Consent: Verbal informed consent was obtained from patient who participated in this case.

Peer-review: Externally peer-reviewed.

Author Contributions: Concept - E.D.; Design - I.I.; Supervision - C.A.; Materials - A.M.; Data Collection and/or Processing - E.D., N.D.; Analysis and/or Interpretation - I.I.; Literature Review - E.D., I.B.; Writer - E.D.; Critical Review - C.A.

Conflict of Interest: The authors declared no conflict of interest.

Financial Disclosure: The authors declared that this study has received no financial support. 
Hasta Onamı: Sözlü hasta onamı bu olguya katılan hastadan alınmıştır.

Hakem değerlendirmesi: Dış bağımsız.

Yazar Katkıları: Fikir - E.D.; Tasarım - İ.I.; Denetleme - C.A.; Malzemeler - A.M.; Veri toplanması ve/veya işlemesi - E.D., N.D.; Analiz ve/veya yorum - I.I.; Literatür taraması - E.D., I.B.; Yazıyı yazan - E.D.; Eleştirel İnceleme - C.A.

Çıkar Çatışması: Yazarlar çıkar çatışması bildirmemişlerdir.

Finansal Destek: Yazarlar bu çalışma için finansal destek almadıklarını beyan etmişlerdir.

\section{References}

1. Oztas P, Gur G, Senlik B, Yalcin B, Polat M, Tamer E, et al. Phytocontact dermatitis due to Ranunculus iliyricus: two cases. J Eur Acad Dermtol Venereol 2006; 20: 1372-3. [CrossRef]
2. Prieto JM, Recio MC, Giner RM, Máñez S, Ríos JL. Pharmacological approach to the pro- and antiinflammatory effects of Ranunculus sceleratus. J Ethnopharmocol 2003; 89: 131-7. [CrossRef]

3. Marion R. Cooper and Anthony W. Jhonson. Poisonous Plants in Britain and their effects on Animals and Man. 1984; 194-8.

4. Dietri Frohne and Hans Jürgen Pfander, Kiel with a foreword by Otmar Wasserman, Kiel Translated from the second German edition by Norman Grainger Bisset A Colour Atlas of Poisonous Plants. (Ranunculi acris L. Meadow Betturcup). 1984; 172-5.

5. Metin A, Calka O, Behçet L, Yildirim E. Phytodermatitis from Ranunculus damascenus. Contact Dermatitis 2001; 44: 183. [CrossRef]

6. Polat M, Oztas P, Yalcin B, Tamer E, Gur G, Alli N. Contact dermatitis due to Allivum satium and Ranunculus illyricus: two cases. Contact Dermatitis 2007; 57: 279-80. [CrossRef]

7. Köse R, Okur MI, Bingöl I, Cetin H. Phytocontact dermtitis mimicking a burn injury due to Ranunculus constantinopolitanus. Contact Dermatitis 2008; 59: 249-50. 